\title{
Evaluation of the Effect of Mathematical Routines on the Development of Skills in Mathematical Problem Solving and School Motivation of Primary School Students in Abitibi-Témiscamingue
}

\author{
Thomas Rajotte $^{1, *}$, Christine Marcotte ${ }^{2}$, Lisa Bureau-Levasseur ${ }^{3}$ \\ ${ }^{1}$ Department of Didactics, University of Quebec, Canada \\ ${ }^{2}$ School Board of Rouyn-Noranda, Canada \\ ${ }^{3}$ Lac Simon Band Council, Canada
}

Copyright $(2016$ by authors, all rights reserved. Authors agree that this article remains permanently open access under the terms of the Creative Commons Attribution License 4.0 International License

\begin{abstract}
In recent decades, the dropout rate in Abitibi-Témiscamingue is a worrying phenomenon. An analysis of ministerial examination results identifies that students in Abitibi-Témiscamingue have specific difficulties with mathematical problem solving tasks. Among the activities that develop those skills, the daily routines in mathematics seem to be a preferred pedagogical approach. The main purpose of this project is to evaluate the effects of doing daily routines in mathematics on two indicators of student success in school: problem solving rates and school motivation. In order to realize the objectives of this research, we implemented two types of activities in classrooms. At first, we used daily routines, which imply five types of logic challenges. Second, we used board games in order to develop children problem solving skills. To meet those objectives, a pretest-posttest, with inequivalent control groups, was implemented. The results show that daily routines in mathematics help to develop problem solving skills of the students in Abitibi-Témiscamingue. Moreover, those routines have an effect on the extrinsic motivation of primary school students in Abitibi-Témiscamingue.
\end{abstract}

Keywords Mathematical Problem Solving, School Motivation, Mathematical Routines, Primary School, Abitibi-Témiscamingue

\section{Introduction}

In recent decades, the dropout rate in Abitibi-Témiscamingue is a worrying phenomenon. In this region, the dropout rate is around $10 \%$ higher from the province's mean [1]. Recent ministerial data shows that the gap between girls' and boys' rate of graduation is the greatest in the province of Québec. In fact, in this region, the boys' dropout rate is around 2.5 times greater than the girl's rate. In 2010-2011, the dropout rate for boys has reached its peak with a $26.6 \%$ level [2]. An analysis of the ministerial examination results identify that students in Abitibi-Témiscamingue have specific difficulties with mathematical problem solving tasks [3]. To complement this data, the Observatory of the Abitibi-Témiscamingue notes that students of this region demonstrate a lack of school motivation [4].

By the challenge they bring, the tasks mobilizing logical challenges are a favoured avenue in order to intervene with boys and girls of primary schools [5]. In fact, on a daily basis, girls appear to be motivated when they invest in short mathematical activities [6]. Moreover, by the competitive nature it brings, playing board games, which implies mathematical components, appears to be a good way to prevent school failure of boys at risk [7]. With the aim of preventing school difficulties, it is important to intervene early in the primary school curriculum and provide motivating activities in mathematics to children [8].

\section{Objectives and Research Questions}

There are two main purposes to this research: (1) to evaluate the effects of daily mathematical routines, which imply logical challenges on school motivation and mathematical problem solving abilities of 3rd grade children who live in Abitibi-Témiscamingue, and (2) to evaluate the effects on those variables of daily routines, which involve mathematical games.

Two research questions of this project come from the objectives presented above: 
- What are the effects of daily mathematical routines, involving logical challenges, on school motivation and mathematical problem solving abilities of 3rd grade students who live in Abitibi-Témiscamingue?

- What are the effects of daily routines, involving mathematical games, on school motivation and mathematical problem solving abilities of 3 rd grade students who live in Abitibi-Témiscamingue?

Moreover, in order to test studies in Education Sciences that categorize practices to motivate boys and girls in mathematics, two supplementary questions are formulated. They are formulated in the following manner:

- What are the effects of daily mathematical routines, involving logical challenges and playing board games, on extrinsic motivation of 3rd grade boys?

- What are the effects of daily mathematical routines, involving logical challenges and playing board games, on extrinsic motivation of 3rd grade girls?

\section{Theoretical Framework}

This research is situated within the constructivist theoretical literature, specifically within cognitive and social constructivism. The cognitive constructivist theory is centred on providing learning contexts and platforms that enable learners to generate experience-based knowledge, individually or through interaction with others [9]. Social constructivism draws on the work of Vygotsky [10][11], Wertsch [12] Wenger [13] and others who conceptualize learning as a co-constructed product of social interaction, through collaborative problem solving, peer engagement and mentorship. Both forms of constructivism are oriented around the belief that effective learning is highly contextualized within authentic (or models of authentic) settings that involve realistic approaches to problem solving.

In order to operationalize, two concepts are relevant to define: problem solving and school motivation.

\section{Problem Solving}

In regard to the concept of problem solving, we mean by problem a situation where a person pursues a goal and does not know immediately the scenario of resolution to achieve this objective [14]. Moreover, according to Poirier [15], the problem must be a reasonable challenge and be accessible to the person. The person facing a given problem needs to develop a series of actions that is within range. To this end, Bair, Haesbroeck and Haesbroeck [16] define problem solving as a research exercise which is, for those who attack it, a "challenge" which mobilizes his abilities and comprehension skills. This approach enables the implementation of knowledge in new situations.

\section{Problem Solving- Addition Field}

At $3^{\text {rd }}$ grade, students who live in Abitibi-Témiscamingue, are able to solve problems within the field of addition. In addition field, three meanings are identified: reunion, comparison and additive change.

The meaning reunion represents the act of juxtaposing two sets of objects. The meaning comparison refers to the act of comparing elements of two sets of objects. Finally, the additive change results in a change in time that transforms the initial state of a set [17].

\section{School Motivation}

Romando [18] defines school motivation as an internal drive that activates behaviour and gives it direction. The term motivation concerns the processes that describe why and how human behaviour is activated and directed. Vallerand, Pelletier, Blais, Brière, Senécal and Vallières [19] identify four components of school motivation: 1) amotivation, which is a lack of motivation, 2) intrinsic motivation, which refers to the fact of undertaking an activity for the satisfaction and pleasure of doing so 3) the identified extrinsic motivation, which consists of behaviour regulation by the free choice a person makes that identifies the reason for its choice; the consequence is external and not linked to pleasure and satisfaction, and 4) introjected extrinsic motivation, which involves behaviour regulation by internalized control sources from the person; these control sources exert pressure on the person.

\section{Methodology}

\subsection{Design and Sample}

In order to answer to the research questions, we used a pretest-posttest quantitative design. Three groups took part in the design: two experimental groups and one control group. In this type of quasi-experimental research design, the use of a control group prevents the possible influence of various concomitant variables (role of family support, socioeconomic level of the students, etc.). The first experimental group $(\mathrm{N}=48)$ participated in a school program which involved daily routines in mathematics (1-Sudoku, 2-chess, 3- find an intruder in a group of objects, 4- match replacing, 5- solving adaptation of Raven's matrices). The duration of the program was two months. The children from the second experimental group had to play mathematical games two hours per week $(\mathrm{N}=33)$. The intervention lasted two months. Finally, the students from the control group didn't participate in a particular school intervention $(\mathrm{N}=38)$. All the participants in the study were 3rd grade students from the region of Abitibi-Témiscamingue (Québec, Canada).

\subsection{Variables of the Study and Evaluation Instruments}

We used two variables to conduct this study. The first variable of the study was school motivation. This variable had four distinct components: intrinsic motivation, 
amotivation, identified extrinsic motivation and introjected extrinsic motivation. To evaluate this variable, we used a tool developed by Vallerand et al. [20]. The instrument was composed by 12 different questions. Cronbach's alpha is established at 0,80 .

The second variable of the study was the mathematical problem solving abilities. In order to evaluate this variable, we built ten mathematical word statements. According to the Théorie des champs conceptuels of Vergnauld [21], the statements evaluated the three meanings of addition. The scale of Voyer [22] was used to evaluate children's score on this dependent variable.

\subsection{Analysis}

In order to compare the three groups score on both dependent variables, we used a covariance analysis (ANCOVA). Those analyses were made on every component of school motivation and every meaning of the addition's fields.

\section{Results}

\subsection{Results for the First Experimental Group}

To evaluate the effects of daily mathematical routines, which involve logical challenges, on school motivation and mathematical problem solving abilities of 3rd grade students who live in Abitibi-Témiscamingue, we made seven ANCOVA. Four ANCOVA were made in order to evaluate the effect of the intervention on the school motivation (one analysis for each component of school motivation) and three ANCOVA were made for each additive meaning considered in our research. To achieve this aim, the results of the first experimental group were compared with the result of the control group. The results of those analyses are presented in Table 1. After that, we made two more ANCOVA in order to evaluate specifically the effects of the daily routines in mathematics on the introjected extrinsic motivation of the $3^{\text {rd }}$ grade boys and girls. The results of those two analyses are presented in Table 2.

The results showed that girls in the first experimental group developed their extrinsic motivation $(\mathrm{F}=5,092$; $\mathrm{p} \leq 0,05)$. A look at Cohen's indicator [23] shows that the effect size of solving logic challenges in mathematics with an introjected extrinsic motivation is important $(\eta 2=0,134)$.

Table 1. Evaluation of the Effects of Mathematical Daily Routines: Results of the ANCOVA

\begin{tabular}{|c|c|c|c|c|c|c|}
\hline $\begin{array}{c}\text { Components of school } \\
\text { motivation }\end{array}$ & Source & df & Mean square & $\mathrm{F}$ & Sig. & $\begin{array}{c}\text { Effect } \\
\text { size }\end{array}$ \\
\hline \multirow{3}{*}{ Identified extrinsic motivation } & Group & 1 & 5,117 & \multirow{3}{*}{$\begin{array}{l}2,234 \\
9,483\end{array}$} & \multirow{3}{*}{$\begin{array}{l}0,140 \\
0,003\end{array}$} & \multirow{3}{*}{0,032} \\
\hline & Pretest & 1 & 21,719 & & & \\
\hline & Error & 68 & 2,290 & & & \\
\hline \multirow{3}{*}{ Amotivation } & Group & 1 & 8,436 & \multirow{3}{*}{$\begin{array}{c}2,302 \\
16,648\end{array}$} & \multirow{3}{*}{$\begin{array}{l}0,134 \\
0,000\end{array}$} & \multirow{3}{*}{0,033} \\
\hline & Pretest & 1 & 61,015 & & & \\
\hline & Error & 68 & 3,665 & & & \\
\hline \multirow{3}{*}{$\begin{array}{l}\text { Introjected extrinsic } \\
\text { motivation }\end{array}$} & Group & 1 & 12,981 & \multirow{3}{*}{$\begin{array}{l}3,945 \\
4,727\end{array}$} & \multirow{3}{*}{$\begin{array}{l}0,066 \\
0,033\end{array}$} & \multirow{3}{*}{0,049} \\
\hline & Pretest & 1 & 17,577 & & & \\
\hline & Error & 68 & 3,714 & & & \\
\hline \multirow{3}{*}{ Intrinsic Motivation } & Group & 1 & 1,487 & \multirow{3}{*}{$\begin{array}{l}3,644 \\
5,538\end{array}$} & \multirow{3}{*}{$\begin{array}{l}0,60 \\
0,22\end{array}$} & \multirow{3}{*}{0,51} \\
\hline & Pretest & 1 & 2,260 & & & \\
\hline & Error & 68 & 0,408 & & & \\
\hline Problem solving meanings & Source & $\mathrm{df}$ & Mean square & $\mathrm{F}$ & Sig. & $\begin{array}{c}\text { Effect } \\
\text { size }\end{array}$ \\
\hline \multirow[t]{2}{*}{ Meaning of reunion } & Pretest & 1 & 0,482 & \multirow{2}{*}{$\begin{array}{l}0,908 \\
0,819\end{array}$} & \multirow{2}{*}{$\begin{array}{l}0,344 \\
0,369\end{array}$} & \multirow{2}{*}{0,013} \\
\hline & Error & 68 & 0,588 & & & \\
\hline \multirow{3}{*}{ Meaning of additive change } & Group & 1 & 1,126 & \multirow{3}{*}{$\begin{array}{l}1,061 \\
8,253\end{array}$} & \multirow{3}{*}{$\begin{array}{l}0,307 \\
0,005\end{array}$} & \multirow{3}{*}{0,015} \\
\hline & Pretest & 1 & 8,759 & & & \\
\hline & Error & 68 & 1,061 & & & \\
\hline \multirow{3}{*}{ Meaning of comparison } & Group & 1 & 0,214 & \multirow{3}{*}{$\begin{array}{c}0,068 \\
11,579\end{array}$} & \multirow{3}{*}{$\begin{array}{l}0,795 \\
0,001\end{array}$} & \multirow{3}{*}{0,001} \\
\hline & Pretest & 1 & 36,501 & & & \\
\hline & Error & 68 & 3,152 & & & \\
\hline
\end{tabular}

Table 2. Evaluation of the Effects of Mathematical Daily Routines: on the Identified Extrinsic Motivation of Both Sexes

\begin{tabular}{|c|c|c|c|c|c|c|}
\hline Identified extrinsic motivation & Source & df & Mean square & $\mathrm{F}$ & Sig. & $\begin{array}{c}\text { Effect } \\
\text { size }\end{array}$ \\
\hline \multirow{3}{*}{ Girls } & Group & 1 & 24,324 & \multirow{3}{*}{$\begin{array}{l}5,092 \\
3,562\end{array}$} & \multirow{3}{*}{$\begin{array}{l}0,031 \\
0,068\end{array}$} & \multirow{3}{*}{0,134} \\
\hline & Pretest & 1 & 17,014 & & & \\
\hline & Error & 33 & 4,777 & & & \\
\hline \multirow{3}{*}{ Boys } & Group & 1 & 0,424 & \multirow{3}{*}{$\begin{array}{l}0,189 \\
0,156\end{array}$} & \multirow{3}{*}{$\begin{array}{l}0,667 \\
0,695\end{array}$} & \multirow{3}{*}{0,006} \\
\hline & Pretest & 1 & 0,350 & & & \\
\hline & Error & 32 & 2,242 & & & \\
\hline
\end{tabular}


Table 3. Evaluation of the Effects of the Board Game Intervention: Results of the Seven ANCOVA

\begin{tabular}{|c|c|c|c|c|c|c|}
\hline $\begin{array}{c}\text { Components of school } \\
\text { motivation }\end{array}$ & Source & $\mathrm{df}$ & Mean square & $\mathrm{F}$ & Sig. & $\begin{array}{c}\text { Effect } \\
\text { size }\end{array}$ \\
\hline \multirow{3}{*}{ Identified extrinsic motivation } & Group & 1 & 5,879 & \multirow{3}{*}{$\begin{array}{l}1,447 \\
5,586\end{array}$} & 0.233 & \multirow{3}{*}{0,017} \\
\hline & Pretest & 1 & 22,702 & & 0,233 & \\
\hline & Error & 82 & 4,064 & & 0,020 & \\
\hline \multirow{3}{*}{ Amotivation } & Group & 1 & 4,234 & \multirow{3}{*}{$\begin{array}{c}0,960 \\
29,285\end{array}$} & & \multirow{3}{*}{0,012} \\
\hline & Pretest & 1 & 129,103 & & 0,330 & \\
\hline & Error & 82 & 4,408 & & 0,000 & \\
\hline \multirow{3}{*}{$\begin{array}{l}\text { Introjected extrinsic } \\
\text { motivation }\end{array}$} & Group & 1 & 12,504 & \multirow{3}{*}{$\begin{array}{c}2,720 \\
29,095\end{array}$} & & \multirow{3}{*}{0,032} \\
\hline & Pretest & 1 & 134,808 & & 0,103 & \\
\hline & Error & 82 & 4,633 & & & \\
\hline \multirow{3}{*}{ Intrinsic Motivation } & Group & 1 & 1,494 & \multirow{3}{*}{$\begin{array}{c}2,148 \\
17,248\end{array}$} & & \multirow{3}{*}{0,026} \\
\hline & Pretest & 1 & 11,993 & & 0,147 & \\
\hline & Error & 82 & 0,695 & & 0,000 & \\
\hline Problem solving meanings & Source & df & Mean square & $\mathrm{F}$ & Sig. & $\begin{array}{l}\text { Effect } \\
\text { size }\end{array}$ \\
\hline \multirow{3}{*}{ Meaning of reunion } & Group & 1 & 1,928 & & & \multirow{3}{*}{0,024} \\
\hline & Pretest & 1 & 0,230 & 2,017 & 0,159 & \\
\hline & Error & 83 & 0,956 & & & \\
\hline \multirow{3}{*}{ Meaning of additive change } & Group & 1 & 7,223 & & & \multirow{3}{*}{0,067} \\
\hline & Pretest & 1 & 0,028 & 5,917 & 0,017 & \\
\hline & Error & 83 & 1,221 & 0,023 & 0,879 & \\
\hline \multirow{3}{*}{ Meaning of comparison } & Group & 1 & 13,513 & & & \multirow{3}{*}{0,037} \\
\hline & Pretest & 1 & 12,944 & $\begin{array}{l}3,211 \\
3,076\end{array}$ & 0,071 & \\
\hline & Error & 83 & 4,208 & & & \\
\hline
\end{tabular}

Table 4. Evaluation of the Effects of Playing Board Games at School on the Identified Extrinsic Motivation of Both Sexes

\begin{tabular}{|c|c|c|c|c|c|c|}
\hline $\begin{array}{c}\text { Identified extrinsic } \\
\text { motivation }\end{array}$ & Source & $\mathrm{df}$ & Mean square & $\mathrm{F}$ & Sig. & $\begin{array}{c}\text { Effect } \\
\text { size }\end{array}$ \\
\hline \multirow{3}{*}{ Girls } & Group & 1 & 0,386 & & & \multirow{3}{*}{0,016} \\
\hline & Pretest & 1 & 10,816 & $\begin{array}{c}0,564 \\
15788\end{array}$ & $\begin{array}{l}0,458 \\
0,000\end{array}$ & \\
\hline & Error & 35 & 0,685 & & 0,000 & \\
\hline \multirow{3}{*}{ Boys } & Group & 1 & 1,434 & & & \multirow{3}{*}{0,086} \\
\hline & Pretest & 1 & 3,984 & $\begin{array}{l}4,160 \\
11560\end{array}$ & 0,047 & \\
\hline & Error & 44 & 0,345 & 11,560 & & \\
\hline
\end{tabular}

\subsection{Results for the Second Experimental Group}

To evaluate the effects of daily mathematical routines, which involve board games, on school motivation and mathematical problem solving abilities of 3rd grade students who live in Abitibi-Témiscamingue, we made seven ANCOVA. Four ANCOVA were made in order to evaluate the effect of the intervention on the school motivation and three ANCOVA were made for each additive meaning we considered in our research. To achieve this aim, the results of the second experimental group were compared with the result of the control group. The results of those analyses are presented in Table 3. Afterwards we made two more ANCOVA in order to evaluate specifically the effects of playing board games at school on the introjected extrinsic motivation of the $3^{\text {rd }}$ grade boys and girls. The results of those two analyses are presented in Table 4.

For the second experimental group, we observed that children developed their ability to solve mathematical problems that involve the transformation meaning of the addition field $(\mathrm{F}=5,917 ; \mathrm{p} \leq 0,05)$. The effect size analysis shows that playing games that involve mathematical components has a moderate impact on the development of the ability to make additions of the transformation meaning $(\eta 2=0,067)$. Moreover, the results show that boys who play mathematical games at school have better results on the introjected extrinsic motivation test $(F=4,160 ; p \leq 0,05)$. The analysis of Cohen's indicator shows that playing mathematical games has an important effect on boys introjected extrinsic motivation $(\eta 2=0,086)$.

\section{Data Interpretation}

Based on the data obtained, we note that participation in a school program where children have to solve mathematical challenges on a daily basis helps them develop their introjected extrinsic motivation. The routines that vary mathematical tasks every day are more motivating for girls and the routines which involve mathematical games are more likely to develop introjected extrinsic motivation for boys. Those results show that daily routines in mathematics, which involve playing games or solving different logical challenges, acts as an external component of school motivation for 3 rd grade children. Moreover, we observe that our activities do not allow students to solve mathematical tasks for the sake of doing so. 
On the other hand, playing mathematical games in school can only develop the meaning transformation of the additive structures. This meaning is characterized by a change in time that acts on an initial state to produce a final state [23]. To explain these results, we hypothesize that the practice of mathematical games specifically solicits actions that lead to effect change or to transform data. Consequently, transformation meaning of additive structures is especially developed by the act of playing games at school.

\section{Limits}

The research design we have chosen involves different bias. Indeed, internal and external sources of invalidity arise from the use of a prestest-posttest quasi-experimental design.

In terms of internal validity, it is important to mention the expectations of the experimenter. In fact, although the lead researcher had developed a pre-established speech to describe the procedures to be followed during the test, teachers had the possibility to intervene during his presentation. Therefore, the lead researcher had to change and adapt its guidelines to explain the instructions in each classroom. Moreover, it is important to consider that it is likely that this approach has caused a social desirability effect. In fact, since the presentation of the guidelines was not performed under rigorous and sequential phases, it is likely that some explanations of the procedures led participants to try to please (or displease) the researcher, when they were answering the research questionnaires.

Secondly, regarding external sources of disability, it is important to mention bias concerning the ecological validity. In fact, it will be difficult to generalize the results to all third-grade children in Abitibi-Témiscamingue. This finding is justified by the fact that the study participants were from the largest city in the Abitibi-Témiscamingue and no student from a rural area of the Abitibi-Témiscamingue has been involved in this research. In addition, it should be noted that the sample used in the statistical analyzes was relatively small. This has significantly reduced the statistical power of our analyses. Consequently, it is possible that the proposed interventions had an effect on other components of school motivation but we were unable to reveal them. Finally, it is important to mention that if the duration of the intervention was longer, the effect size of the intervention on the introjected extrinsic motivation could easily have been higher.

\section{Conclusions}

Finally, after conducting this study, we firmly recommend educators to implement activities involving a daily routine of logical challenges or free practice of mathematical games. These activities can contribute to develop the introjected extrinsic motivation of 3rd grade students and their skills in solving problems involving specifically the meaning transformation of the addition field. This study was conducted in Abitibi- Témiscamingue, but it could be replicated elsewhere. Other research, which uses a qualitative design, should be conducted to explore these findings and explain how these daily math routines influence school student motivation.

\section{Acknowledgements}

We are very grateful to $3^{\text {rd }}$ grade expert teachers for their participation to this research project. Moreover, we thank Rouyn-Noranda's school board for their permission to conduct this study.

\section{REFERENCES}

[1] Action Réussite. La persévérance scolaire en Abitibi-Témiscamingue. État de la situation. Action Réussite, Rouyn-Noranda. 2013.

[2] Ministère de l'Éducation, du Loisir et du Sport. Bilan 4 du système Charlemagne. Document inédit. Gouvernement du Québec, Québec, 2014a.

[3] Ministère de l'Éducation, du Loisir et des Sports, système Charlemagne. Taux de réussite pour chaque épreuve unique de juin 2013, par organisme scolaire. Document inédit. Gouvernement du Québec, Québec. 2014b.

[4] Observatoire de l'Abitibi-Témiscamingue. Portrait de l'éducation et de la formation de la main- d'œuvre. Observatoire de l'Abitibi-Témiscamingue, Rouyn-Noranda. 2007.

[5] S.K. Reed. Cognition: Théories et applications. Paris: De Boeck Université, 2007.

[6] A. Norfleet James. Enseigner les mathématiques et les sciences aux filles: stratégies pour un enseignement différencié. Chenelière Éducation, Montréal, 2010.

[7] T. Rajotte, D. Voyer. La pratique des échecs en milieu scolaire: un moyen de privilégier la réussite éducative des élèves du primaire. Presses Académiques Francophones, Saarbrücken, 2012.

[8] National Council of Teachers of Mathematics. Principles and standards for school mathematics. NCTM, Reston, 2008.

[9] V. Dennen, S. Hao. Paradigms of use, learning theory and app design. In C. Miller, A. Doering (Eds.). The new landscape of mobile learning. New York: Routledge, 2014.

[10] L. Vygotsky. Thought and language (translation). Cambridge: MIT Press, 1962.

[11] L. Vygotsky. The genesis of higher mental functions. In J. Wertsch (Ed.). The concept of activity in Soviet psychology. Cambridge, MA: Harvard University Press, 1981. 
[12] J. Wertsch. Vygotsky and the social formation of mind. Cambridge, MA: Cambridge UniversityPress, 1985.

[13] E. Wenger. Communities of practice. Learning meaning and identity. Cambridge, England, 1988.

[14] J. Tardif. Pour un enseignement stratégique: l'apport de la psychologie cognitive. LOGIQUES, Montréal, 1992.

[15] L. Poirier. Enseigner les maths au primaire: notes didactiques. Éditions du renouveau pédagogique inc., Québec, 2001.

[16] J. Bair. G. Haesbroeck, J.J. Haesbroeck. Formation mathématique par la résolution de problèmes. DeBoeck Université, Bruxelles, 2000.

[17] Romando, R. Motivation Theory. Ezine Articles. Online available http://ezinearticles.com/?Motivation-Theory\&id=410700

[18] R.J. Vallerand, L.G. Pelletier, M.R. Blais, N.M. Brière, C.B. Sénécal, E.F. Vallières. On the assessment of intrinsic, extrinsic, and amotivation in education: Evidence on the concurrent and construct validity of the Academic Motivation Scale. Educational and Psychological Measurement, 53, 159-172, 1993.

[19] Ibid.

[20] L. Poirier. Enseigner les maths au primaire: notes didactiques. ERPI, Saint-Laurent, 2001.

[21] G. Vergnauld. La théorie des champs conceptuels. Recherches en didactique des mathématiques, 10(2-3), 133-170, 1990.

[22] D. Voyer. La résolution de problèmes: Régler des maux en changeant des mots! Éditions de la Bande Didactique, Montréal, 2009.

[23] J. Cohen. Statistical power analysis for the behavioural sciences. Hillsdale: Lawrence Erlbaum, 1988.

[24] G. Vergnauld. La théorie des champs conceptuels. Recherches en didactique des mathématiques, 10(2-3), 133-170, 1990. 